\title{
ADDIKTOLÓGIAI PSZICHOLÓGIA MAGYARORSZÁGON: AZ ELMÚLT 30 ÉV ÁTTEKINTÉSE
}

\author{
DEMETROVICS ZSOLT ${ }^{1 *}-$ RÁCZ JÓZSEF $^{1,2}$
}

${ }^{1}$ ELTE Eötvös Loránd Tudományegyetem, Pszichológiai Intézet, Budapest, Magyarország

${ }^{2}$ Semmelweis Egyetem, Egészségtudományi Kar, Addiktológiai Tanszék

E-mail: demetrovics.zsolt@ppk.elte.hu

Beérkezett: 2021. november 11. - Elfogadva: 2021. december 12.

A tanulmány célja az addiktológiai szakterület elmúlt harminc-negyven évének áttekintése, a legfontosabb fejlemények, kutatási területek és eredmények összefoglaló bemutatása. A szerzók az addiktológiai pszichológia történetében három fázist azonosítanak. A 80-as évek kezdeti törekvéseit a 90-es évek közepétól a szakterület jelentốs megerösödése és hazai kibontakozása követte, míg a 2000-es évek második felétól már a nemzetközi jelenlét a meghatározó. A történeti összefoglalót követôen a szerzók az egyes meghatározó kutatócsoportokat és kutatási irányokat mutatják be, majd a legfontosabb szakmai közéleti fejleményeket ismertetik.

Kulcsszavak: addiktológia, pszichológia, történet, kutatási irányok

\footnotetext{
* levelező szerzó
} 


\section{AZ ADDIKTOLÓGIAI KUTATÁSOK KEZDETE MAGYARORSZÁGON}

A droghasználat hazai megjelenésérôl, amely ebben az időszakban az alkoholhasználat mellett elsôsorban a gyógyszerekkel való visszaélést és a szerves oldószerek használatát (szipuzás) jelentette, a 60-as évek második felétôl kezdôdően történtek jelzések (Kisszékelyi, 1973, 1975, 1979), de a probléma tényleges és jelentôsebb mértékú kibontakozása, a drogszcénák megjelenése valójában a 80-as, 90-es évekre tehetô. Ez az idôszak, a 80-as évek második fele az, amikor a szakterület kialakulása is érdemi fejlôdésnek indult, így az addiktológiai pszichológia elmúlt 30 éve lényegében a szakterület megjelenésének és kibontakozásának teljes idôszakát felöleli. Az addiktológiai kutatások - részben a devianciakutatás, részben az addiktológiai pszichiátriai kutatások keretében - a 80-as évek második felétôl indulhattak el Magyarországon. A devianciakutatás a „társadalmi beilleszkedési zavarok komplex elemzése”, röviden a TBZ kutatási föirány keretében zajlott, amelynek Pataki Ferenc volt az elnöke, Andorka Rudolf az alelnöke. Nagy létszámú, multidiszciplináris kutatói kör (orvos, jogász, pszichológus, szociológus, közgazdász stb.) vett részt benne. Ezt a kezdeti idôszakot olyan kutatások jelentették, mint az alkohol-és drogepidemiológiai kutatások elindulása (Elekes Zsuzsanna munkái a Marx Károly Közgazdaságtudományi Egyetemen [ma Budapesti Corvinus Egyetem]) és a Rácz József vezetésével folyó, a droghasználó ifjúsági szubkultúrák megismerését célzó etnográfiai és szociálpszichiátriai kutatások (MTA Pszichológiai Kutatóintézet [ma ELKH TTK Kognitív Idegtudományi és Pszichológiai Intézet]). Idesorolhatók a Gerevich József vezetésével folyó, elsôdlegesen klinikai fókuszú $a d$ diktológiai pszichiátriai/pszichológiai kutatások (Drogmegelőzési Módszertani Központ és Ambulancia) és a Cserne István és Hoyer Mária (Klapka utcai Drogambulancia [késóbb Jász utcai Drogambulancia; jelenleg Nyírô Gyula Kórház - OPAI Drogambulancia, Drogbeteg Gondozó és Prevenciós Központ) részvételével megjelenô, szintén klinikai fókuszú, elsôsorban terápiás jellegú munkák.

Ezt az idôszakot dominánsan a magyar nyelvú közlések, illetve egyes szakmai kiadványok lefordítása és megjelentetése jellemezte. Különösen utóbbiak vonatkozásában erôteljes cél volt az alakuló, formálódó klinikai addiktológiai ellátás támogatása, illetve a szintén lassan kibontakozó prevenciós terület szakmai megalapozása. A 80-as évek végére, 90-es évek elejére megjelent néhány olyan kulcs összefoglaló írás (Gerevich, 1992; Rácz, 1988a), amely jelezte már a szakma formálódását, az alapok lerakását. Ebbôl az idôszakból szintén megemlítendôk Levendel (Levendel, 1987), Buda (Buda, 1981, 1992) és Andorka (Andorka, 1987, 1988, 1994; Andorka és mtsai, 1986) munkái, amelyek fôképp az alkoholizmus területén születtek. Ezek elsôsorban az alkohológia, a szociológia és a szociálpszichológia felôl írták le az alkoholproblémák hazai jellegzetességeit.

\section{A SZAKMAI KIBONTAKOZÁS IDŌSZAKA}

A 90-es évek elejétôl, közepétől jelentôsen megindult az addiktológia szakterületének fejlôdése. Ezt az idôszakot nagyobbrészt a klinikai (pszichiátriai, klinikai pszichológiai) ellátás támogatása, a drogprevenciós tevékenységek elôsegítése és az ártalom- 
csökkentô szolgáltatások megalapozása erôsítette. Ebben az idôszakban különösen szoros együttmúködésben alakult az addiktológia különbözô alkalmazott területeinek és tudományos megalapozásának fejlődése. Létrejöttek az elsô szakmai szervezetek (Magyar Addiktológiai Társaság [1994], Magyar Drogterápiás Intézetek Szövetsége [1995]), és megrendezésre kerültek az elsô szakmai konferenciák. Buda Béla 1993-ban útjára indította a Szenvedélybetegségek (Addictologia Hungarica) címú szaklapot, amely a hazai addiktológia meghatározó lapja lett. Ennek előzménye az 1970-80-as években az Alkohológia (főszerkesztô: Andorka Rudolf) volt.

Az idôszak máig tartó hatású drogpolitikai dokumentuma a Nemzeti Drogstratégia (Nemzeti stratégia a kábítószer-probléma visszaszorítására) (Országgyúlés, 2000), amelynek nyomán forrás nyílt meg az ellátások-szolgáltatások fejlesztésére, így az addiktológiai kutatásokra is. A Felvinczi Katalin vezetésével megalakuló Nemzeti Drogmegelózési Intézet (2001-2016) elsôsorban a prevencióval kapcsolatos kutatásokat facilitálta, illetve könyvsorozatok (sorozatszerkesztôk Buda Béla és Demetrovics Zsolt) támogatásával publikációs lehetôséget teremtett kutatók számára, valamint hozzájárult a szakma továbbképzéséhez, s a szélesebb értelemben vett érdeklődôk tájékoztatásához is. A Kutatások (L'Harmattan Kiadó) könyvsorozatban 15 kötet jelent meg 2001 és 2011 között, míg az elméleti-módszertani múveket megjelentetô Elméletek-modellek (L'Harmattan Kiadó) sorozatban 5 kötet látott napvilágot. Még korábbi idôszakban, 2003-2007 között jelent meg hét fordításkötet A drogtörténet klasszikusai, illetve a Szenvedélyek (EDGE 2000 Kiadó és Nyitott Könyvmúhely Kiadó) sorozatokban. Speciális helyet foglalt el a sorozatok között a Sorsok és Szenvedélyek sorozat (L’Harmattan Kiadó), amelyben önéletrajzi írások, szépirodalmi múvek jelenhettek meg. A Nemzeti Drogmegelôzési Intézet felbomlásával ezen sorozatok sorsa bizonytalanná vált, 2018-tól azonban az ELTE Pedagógiai és Pszichológiai Kar, valamint a L'Harmattan Kiadó együttmúködésében újraindult a Sorsok és Szenvedélyek sorozat, illetve RendSzerTan - Addiktológiai Elméletek és Kutatások címmel az elméleti és empirikus munkák kiadása is megújult (sorozatszerkesztôk Demetrovics Zsolt, Felvinczi Katalin és Rácz József).

A drogmonitorozás európai uniós intézményrendszerének hazai központjaként megalakult a Nemzeti Kábítószer Adatgyújtô és Kapcsolattartó Központ, azaz a Nemzeti Drogfókuszpont (2004). Ez a szervezet adja ki a 2000-es években még az Ifjúsági és Sportminisztérium, majd az utódminisztériumok által megjelentetett Jelentés a magyarországi kábítószerhelyzetról címú éves kiadványt. Az elôször 1999-ben megjelent kiadvány (Ritter és Topolánszky, 1999) tartalmazza a hazai addiktológiai kutatások öszszefoglalóit, a drogfogyasztás indikátorait is, így bemutatja a statisztikai regisztrátumok alakulását is az epidemiológia, a prevenció, a kezelés-ellátás és a kábítószer-bûnözés tekintetében.

Ebben az idôszakban indultak el Pikó Bettina (SZOTE Népegészségtani Intézet, majd 1998-tól SZOTE Pszichiátriai Klinika, Magatartástudományi Csoport) szegedi és dél-alföldi ifjúságkutatásai, és jelentek meg elsố könyvei (Pikó, 2002, 2005a, 2005b, 2006, 2010). A kutatások fókuszában a magatartás-epidemiológia, az egészség pszichoszociális reprezentációja és a kockázatészlelés állt.

Szintén ebben az idôszakban jelentek meg az oktatásban máig használt alapmúvek: Rácz József Addiktológia. Tünettan és intervenció címú könyve (Rácz, 1999), a Demetrovics Zsolt szerkesztette Az addiktológia alapjai I-IV. (Demetrovics, 2007a, 2009a, 2009b; 
Demetrovics és Kun, 2010), valamint Gerevich József (Gerevich, 1992), Kelemen Gábor (Kelemen, 1994, 2009), Buda Béla (Buda, 1992, 1995) és Pikó Bettina (Pikó, 2005a, 2005b) könyvei.

\section{A NEMZETKÖZI ADDIKTOLÓGIA FÖSODRÁBAN}

Az elmúlt egy-másfél évtizedben a 2000-es évek elejére, közepére kialakult kutatócsoportok tovább erôsödtek, s megkezdôdött a hazai addiktológiai kutatás újabb generációjának megjelenése, megerôsödése. Növekvő számú doktori értekezés (PhD), és több MTA-doktori értekezés is született a témában (Demetrovics, 2014; Elekes, 2012; Pikó, 2013; Rácz, 2009; Szabó, 2016; Urbán, 2016).

Ezen idôszak leginkább meghatározó jellemzôje, hogy a kutatómunka és a publikációs tevékenység nemzetközi színtérre került. Míg a korábbi időszakot jellemzően a hazai közlemények dominálták, a 2000-es évek végétôl már egyértelmúen a nemzetközi lapokban, nemzetközi konferenciákon jelentek meg a hazai eredmények, gyakran nemzetközi együttmúködés keretében. A következó évtizedben több kutatócsoport jelentôs nemzetközi ismertségre és elismertségre tett szert, és a szakterület sikeresnek mutatkozott a nemzetközi pályázatok elnyerésében is.

\section{KUTATÓK ÉS KUTATÓCSOPORTOK A HAZAI ADDIKTOLÓGIÁBAN}

A következókben az addiktológiai pszichológia leginkább meghatározó kutatócsoportjainak, személyiségeinek munkásságát foglaljuk össze röviden, legfőbb eredményeikre, kutatási irányukra szorítkozva. Ezt követôen az addiktológia egyes részterületeinek, témáinak fejlődését tekintjük át.

Gerevich József (Drogmegelőzési Módszertani Központ és Ambulancia, majd késôbb Addiktológiai Kutatóközpont) az 1980-as évektôl az addiktológiai medicina, az addiktológiai pszichiátria hazai megteremtéséhez járult hozzá. Munkatársával, Bácskai Erikával az addiktológiai pszichológia területén az addiktológiai ellátási modellek kritikai értékelésével foglalkoztak (Gerevich, Bácskai és Rózsa, 2003), kiemelve a közösségi mentálhigiéné, az iskolai prevenció és a kortárs segítés szerepét (Gerevich és Bácskai, 1995). Kollégáikkal emellett epidemiológiai kutatásokat végeztek (Bácskai és Gerevich, 1997, 2006; Gerevich és Bácskai, 2017), pszichometriai mérốeszközök fejlesztésében vettek részt (Gerevich és Bácskai, 2012). Gerevich elsôként indított el átfogó képzést az drogambulanciákon dolgozó szakembereknek 1988-ban.

Rácz Józsefaz 1980-as évektől az MTA Pszichológiai Intézetében, majd párhuzamosan 1997-tôl a SE ETK Addiktológiai Tanszékén (illetve jogelődjeinél) is, 2011-tôl pedig az ELTE PPK Pszichológiai Intézetében kvalitatív addiktológiai kutatásokkal, illetve egyes drogpolitikai beavatkozások szakmai-tudományos megalapozásával foglalkozik. Nevéhez füzôdik a hazai kvalitatív drogkutatás megteremtése, a Kék Pont Drogkonzultációs Központ és Ambulancia megalapítása és múködtetése (1998-tól) és az addiktológiai konzultáns képzés megalapítása és vezetése a Semmelweis Egyetemen (1997). Ifjúsági szubkultúrákkal és fiatalkori devianciákkal kapcsolatos, részt vevô megfigyelésen és 
1. táblázat. Az addiktológiai pszichológia legmeghatározóbb kutatócsoportjai, személyiségei és fốbb kutatási irányaik

\begin{tabular}{|l|l|l|}
\hline Kutató neve & Kutatóhely* & Fóbb témák \\
\hline Gerevich József & $\begin{array}{l}\text { Addiktológiai Kutatóköz- } \\
\text { pont }\end{array}$ & $\begin{array}{l}\text { addiktológiai medicina, méróeszkö- } \\
\text { zök adaptálása }\end{array}$ \\
\hline Rácz József & ELTE Pszichológiai Intézet & $\begin{array}{l}\text { etnográfiai kutatások, kvalitatív } \\
\text { drogkutatások, ifjúsági szubkultúrák, } \\
\text { szegregátumok droghasználata }\end{array}$ \\
\hline Elekes Zsuzsanna & $\begin{array}{l}\text { BCE Társadalomepidemio- } \\
\text { lógiai Kutatócsoport }\end{array}$ & $\begin{array}{l}\text { alkohol- és drogepidemiológiai ku- } \\
\text { tatások }\end{array}$ \\
\hline Kelemen Gábor & $\begin{array}{l}\text { PTE Közösségi és Szociális } \\
\text { Tanulmányok Tanszéke }\end{array}$ & $\begin{array}{l}\text { addiktológiai pszichológia ismeret- } \\
\text { elméleti, nyelvi-kommunikációs } \\
\text { vizsgálata }\end{array}$ \\
\hline Paksi Borbála & $\begin{array}{l}\text { ELTE Neveléstudományi } \\
\text { Intézet }\end{array}$ & $\begin{array}{l}\text { epidemiológia, szerhasználó maga- } \\
\text { tartások társadalmi mintázódása, } \\
\text { prevenciós programok értékelése }\end{array}$ \\
\hline Pikó Bettina & $\begin{array}{l}\text { SZTE Magatartástudományi } \\
\text { Intézet }\end{array}$ & $\begin{array}{l}\text { magatartás-epidemiológia, pozitív } \\
\text { egészségpszichológia alapú ifjúság- } \\
\text { kutatás }\end{array}$ \\
\hline Demetrovics Zsolt & ELTE Pszichológiai Intézet & $\begin{array}{l}\text { pszichoaktívszer-használat és viselke- } \\
\text { dési addikciók epidemiológiája, etio- } \\
\text { lógiája, méróeszközök fejlesztése }\end{array}$ \\
\hline Urbán Róbert & ELTE Pszichológiai Intézet & $\begin{array}{l}\text { a dohányzás prediktív és protektív } \\
\text { tényezóinek vizsgálata, egészségpszi- } \\
\text { chológiai kutatások }\end{array}$ \\
\hline Szabó Attila & $\begin{array}{l}\text { ELTE Egészségfejlesztési } \\
\text { és Sporttudományi Intézet }\end{array}$ & $\begin{array}{l}\text { testedzésfüggóség, problémás mobil- } \\
\text { telefon-használat }\end{array}$ \\
\hline Kapitány-Fövény Máté & $\begin{array}{l}\text { SE ETK Addiktológiai Tan- } \\
\text { széke, OPAI-Nyírố Gyula } \\
\text { Kórház Drogambulanciája }\end{array}$ & $\begin{array}{l}\text { helyettesító kezelésben részt vevó́ } \\
\text { betegek vizsgálata, új pszichoaktív } \\
\text { szerek használata }\end{array}$ \\
\hline Klinika
\end{tabular}

* Kutatóhelyként az aktuális munkahelyet tüntetjük fel

interjúfelvételen alapuló kutatásaiból (Rácz, Göncz és Kéthelyi, 1984) alakította ki az 1990-es években a kvalitatív pszichológiai irányt (Rácz, 1992). A Kék Pont Alapítvány kliensköre, különösen a belpesti szegregátumban múködô tû́csereprogramja lehetôvé tette a kezelésbe jutás pszichoszociális tényezôinek kutatását. Így került sor az ártalomcsökkentés, az ambuláns kezelés és a felépülési modell drogpolitikai összetevôinek, és kliensoldali, a kliensek megélt tapasztalatainak vizsgálatára.

Elekes Zsuzsanna az 1980-as évektôl a jelenlegi BCE Kommunikációs és Szociológiai Intézet, Szociológia és Társadalompolitika Tanszékén, jelenleg a Társadalomepidemiológiai Kutatócsoportban vezet epidemiológiai kutatásokat. Témája a pszichoaktívanyag- (elsốsorban az alkohol-) használat elófordulása a hazai népességben, illetve középiskolások körében (Elekes, 2009; Elekes, Arnold és Bencsik, 2020). 1995-ben Paksi Borbálával közösen kapcsolódtak be az induló nemzetközi ESPAD (European School Survey Project on Alcohol and other Drugs) kutatásba. Ennek pilot kutatása 1992-ben 
volt, amely az elsô, nemzetközi standardoknak megfelelô drogepidemiológiai kutatás volt Magyarországon (Elekes és Paksi, 1994, 1996).

Kelemen Gábor, B. Erdôs Márta és kollégáik (PTE BTK Közösségi és Szociális Tanulmányok Tanszéke) az 1990-es évektôl az addiktológiai pszichológia ismeretelméleti, nyelvi-kommunikációs megalapozásával foglalkoznak. Kutatásaik a hazai addiktológiai ellátórendszer kritikai értékelését célozzák, kiemelve az egészségügy és a szociális terület összekapcsolásának fontosságát, a multiprofesszionális munkacsoportok szerepét, az egészségtanulás jelentôségét (Erdôs és mtsai, 2018; Erdôs és Kelemen, 2015; Kelemen, 2001, 2009, 2011).

Paksi Borbála az 1990-es évektôl végez a szenvedély-magatartásokkal kapcsolatos kutatásokat (Elekes és Paksi, 2000; Paksi, 2003). Az addiktológia területén készült magyarországi lakossági vizsgálatok mindegyike az ó vezetésével zajlott, s a speciális populációs kvantitatív drogepidemiológiai vizsgálatok területén (pl. hajléktalan-, államigondozott-, fogvatartott-populációk) is meghatározó tevékenységet végzett. Munkájának fókuszában a szerhasználó magatartások társadalmi mintázódásának, valamint a mérés módszertani problémáinak vizsgálata (Paksi, Demetrovics, Griffiths, Magi és Felvinczi, 2020) áll, emellett foglalkozik az iskolai prevenció monitorozásával és értékelésével is (Paksi és Demetrovics, 2002, 2011). Jelenleg az ELTE PPK Neveléstudományi Intézetében dolgozik.

Pikó Bettina és kollégái (SZTE ÁOK Magatartástudományi Intézet) kutatásai két témakört érintettek: magatartás-epidemiológiai vizsgálatokat és a pozitív egészségpszichológia alapú ifjúságkutatást (Lázár és Pikó, 2012; Pikó, 2000, 2005a, 2005b, 2010).

Demetrovics Zsolt a 1990-es évek közepétôl végez vizsgálatokat a pszichoaktívszer-használat epidemiológiai, pszichológiai, családi vonatkozásai tekintetében (Demetrovics, 2007b, 2007c), illetve a 2000-es évek elejétôl a különbözô viselkedési addikciók vonatkozásában is az ELTE Pszichológiai Intézetében (2006-ban vezetésével alakul meg az Addiktológiai Tanszéki Szakcsoport, amely 2011-ben alakul tanszékké [Klinikai Pszichológia és Addiktológia Tanszék]). A vezetésével múködő Addiktológiai Kutatócsoport fókuszában a pszichoaktívszer-használat, a viselkedési addikciók epidemiológiai, etiológiai, valamint klinikai és egészségpszichológiai célú vizsgálata, továbbá az ezen jelenségekkel kapcsolatos prevenciós és terápiás intervenciók monitorozása és értékelése, mérési eljárások kifejlesztése áll. Demetrovics vezetésével itt került kialakításra tanár szakos hallgatók számára a Drogprevenciós és Egészségfejlesztési Program (2002-2010), illetve az Addiktológiai Program (2005-2010).

Urbán Róbert számos módszertani hozzájárulása mellett elsôdlegesen a dohányzás prediktív és protektív tényezőinek vizsgálata, illetve tágabban az egészségpszichológia területén végzett kutatásai révén járult hozzá a hazai addiktológia fejlôdéséhez. Demetrovics Zsolttal együtt számos szer- és viselkedéses függôség motivációs bázisának pszichometriai megközelítésével nemzetközi szinten is használt mérôeszközök kidolgozását végezte el ebben az idôszakban.

Szabó Attila (ELTE PPK Egészségfejlesztési és Sporttudományi Intézet) elsôdlegesen a testedzés-függôség, illetve a problémás mobiltelefon-használat terén végez nemzetközi viszonylatban is meghatározó kutatómunkát. Részt vett az Exercise Addiction Inventory (Terry, Szabó és Griffiths, 2004) kialakításában, illetve több, az okostelefonok 
használatával kapcsolatos méróeszköz adaptálásában (Csibi, Griffiths, Cook, Demetrovics és Szabó, 2018).

Kapitány-Fövény Máté az SE ETK Addiktológiai Tanszékén és az OPAI-Nyírô Gyula Kórház Drogambulanciáján végzi kutatásait, utóbbi helyen Farkas Judittal közösen. Kutatási területe többek között a helyettesítô kezelésben részt vevó betegek vizsgálata az új pszichoaktív szerek (ÚPSZ) tekintetében (Kapitány-Fövény, Farksas és mtsai, 2017). A prevenció területén több úttörő kezdeményezést fejlesztett ki (KapitányFövény és mtsai, 2018).

Andó Bálint és munkatársai (SZTE ÁOK Pszichiátriai Klinika) az alkoholfüggôség neurokognitív és személyiségpszichológiai vizsgálatával foglalkoznak, fóként a Cloninger-féle bioszociális modell vonatkozásában (pl. Andó és mtsai, 2014; Kovács, Demeter és mtsai, 2020; Kovács, Pribék és mtsai, 2020).

\section{AZ ADDIKTOLÓGIAI PSZICHOLÓGIA FŐBB KUTATÁSI IRÁNYAI}

\section{Epidemiológia}

A társadalmi addiktológiai problémák megismeréséhez az epidemiológiai adatok jelentik a kiindulópontot. Az addiktológiai pszichológia szempontjából az epidemiológiai adatfelvételekhez társuló, a pszichoszociális jellemzôket figyelembe vevô, vagy éppen speciális pszichológiai kérdésfelvetéssel dolgozó vizsgálatokat kell kiemelnünk, melyek közül három, hullámokban ismétlôdô, országos epidemiológiai kutatást említünk.

Az Iskoláskorú gyermekek egészségmagatartása (Health Behaviour in School-aged Children, HBSC) nemzetközi kutatás 1985-ben indult el, Magyarország Aszmann Anna vezetésével két évvel késôbb kapcsolódott be a kutatásba. Célja a 11-17 éves korosztály egészséget befolyásoló szokásainak és szubjektív egészségi állapotának feltérképezése. A hazai kutatócsoportot jelenleg Németh Ágnes vezeti (ELTE Pszichológiai Intézet). Az Európai iskolavizsgálat a fiatalok alkohol- és egyéb drogfogyasztási szokásairól (European School Survey on Alcohol and other Drugs, ESPAD) elnevezésú felmérés Elekes Zsuzsanna (BCE) által koordinált nemzetközi kutatás, amely 1995-ben indult el. Célja, hogy nemzetközileg összehasonlítható adatokat gyújtsön a fiatalok dohányzásáról, alkohol- és egyéb drogfogyasztási szokásairól. A fentiek mellett Magyarországon elôször 2001-ben készült célzottan a felnôtt népesség pszichoaktívszer-használatának feltárására irányuló epidemiológiai vizsgálat (Alkohol és Drogepidemiológiai Vizsgálat [ADE] 2001 [Paksi, 2003]), majd ezt követôen további négy alkalommal zajlottak az általános populációban a különbözô addiktológiai problémák vizsgálatára irányuló, a nemzetközi standardokat leképezô epidemiológiai kutatások: az ADE 2003 (Elekes és Paksi, 2004), az Országos Lakossági Adatfelvétel Addiktológiai Problémákról (OLAAP) 2007 (Paksi, Rózsa, Kun, Arnold és Demetrovics, 2009), az OLAAP 2015 (Paksi, Demetrovics, Magi és Felvinczi, 2017) és az OLAAP 2019 (Paksi és Demetrovics, 2021). Az utóbbi három kutatási hullám tematikája már a pszichoaktívszer-használat mellett a legelterjedtebb viselkedési addikciók vizsgálatára is kiterjedt. Az OLAAP-kutatások kutatásvezetôje Paksi Borbála (ELTE Neveléstudományi Intézet). Mindhárom program az 
addiktológiai problémák pszichoszociális összetevőivel is foglalkozik, kiegészítô adatfelvételekkel pedig specifikus addiktológiai pszichológiai kérdések megválaszolására is alkalmasak: pl. érzelmi intelligencia (Kun és mtsai, 2019), az impulzivitás méróeszközének kialakítása (Kapitány-Fövény, Urbán és mtsai, 2020), szerhasználói tipológiák (Horváth és mtsai, 2019; Urbán és mtsai, 2019).

Az epidemiológiai kutatások között soroljuk fel a magatartás-epidemiológiai és a pozitív egészségpszichológia alapú ifjúságkutatásokat. A magatartás-epidemiológiai kutatások a rizikó- és protektív elméletre épülnek. Témái közül a társadalmi egyenlốtlenségek vizsgálatát emeljük ki. A pozitív egészségpszichológiai kutatásokból pedig az egészséges önbizalom, pozitív önértékelés és a spirituális jóllét mint univerzális védôfaktorok vizsgálatát hangsúlyozzuk. Pikó Bettina és Ifjúságkutató Munkacsoportja vizsgálja az elôzốek mellett - többek között - a szüloói nevelési stílus és a szülooi azonosulás szerepét a serdülōo és fiatalkori addikciós problémák kialakulásában. Ezen kutatások elsôsorban a hatékony prevenció megalapozásához járulnak hozzá.

\section{Szakpolitikai támogatás}

Az addiktológiai pszichológia múvelôi az 1980-as évektôl kezdődôen feladatuknak érezték, hogy szakértôként hozzájáruljanak szakpolitikai programok kidolgozásához. Az alkohol- és drogpolitika kereslet-kínálati oldalai közül a kutatások elsôsorban a keresleti oldallal foglalkoztak. Kiemelt szerepet kapott a kezelési-ellátási lánc kiépítése: az alacsony küszöbú, ártalomcsökkentô beavatkozásoktól kezdve a korai kezelésbe vételt lehetôvé tevô programokon át a multiprofesszionális munkacsoportok által koordinált terápiás programokig, melyek célja a felépülés elôsegítése. Már az 1980-as évek második felétôl számos, az ellátási helyzetet kritikusan leíró tanulmány jelent meg, amelyek egyben javaslatokat is tartalmaztak a lehetséges beavatkozási irányokra vonatkozóan (pl. Gerevich, 1988, 1989; Rácz, 1988b). Elôadások és tanulmányok sora foglalkozott az egészségügyi és a szociális rendszerek összekapcsolásával, a specializált addiktológiai és pszichiátriai szolgáltatások, valamint az alapellátás integrálásával (pl. Demetrovics és Kun, 2011; Kelemen, 2011). A gyakorlatban is múködô, hatékony klinikai ellátás kialakítása azonban még mindig várat magára.

Nemzetközileg, de Magyarországon is tapasztalható, hogy a drogpolitikai modellekkel kapcsolatban mindig is szakmai-tudományos-ideológiai megosztottság uralkodik, ahol az addiktológiai pszichológia múvelôi a tudományos megalapozottság, a bizonyítékokon alapuló modellek mellett érvelnek (Bőthe, Baumgartner, Schaub, Demetrovics és Orosz, 2020; Demetrovics, 2003a; Demetrovics, Farkas, és mtsai, 2009; Gyarmathy és mtsai, 2016; King és mtsai, 2018; Petke és mtsai, 2011; Rácz, 2005; Rácz, Melles, Márványkövi, Lencse és Petke, 2011; Rumpf és mtsai, 2019). Újra és újra tanúi vagyunk a tudományosan nem megalapozott, ideológiailag elkötelezett, esetleg „olcsó” - de szakmailag nem alátámasztott - módszerek iránti megrendelések jelentkezésének, amelyeket megfeleló érvekkel kell elutasítanunk.

A terület szakemberei részt vettek az elsố nemzeti drogstratégia kidolgozásában és tudományos megalapozásában (Országgyúlés, 2000), majd annak értékelésében (Vitrai, 2009). Utóbbi nemzetközileg is kiemelkedő jelentôségú volt. A szakma kép- 
viselôi szoros kapcsolatot tartottak és tartanak fenn az EU kábítószerügyi tudományos szervezeteivel, pl. Kábítószer és Kábítószer-függôség Európai Megfigyelôközpontja (European Monitoring Centre for Drugs and Drug Addiction, EMCDDA), illetve nemzetközi projektekben vesznek részt. Ide kapcsolható Magyarország intenzívebb részvétele az Európa Tanács Pompidou Csoportjának munkájában a 2000-es évek második felében (Demetrovics, 2010), illetve aktuálisan a DSM (Diagnostic and Manual of Mental Diseases) és a Betegségek Nemzetközi Osztályozása revíziója körüli szakmai vitában történt részvételünk is (Griffiths, King és Demetrovics, 2014; Griffiths és mtsai, 2016; Király és Demetrovics, 2017; Király, Griffiths és Demetrovics, 2015; Müller és mtsai, 2019; Rumpf és mtsai, 2018).

\section{Prevenciós kutatások}

Az iskolai prevenció és az iskolai egészségfejlesztés az addiktológiai pszichológia egyik fontos alkalmazása. Már az 1980-as évektól kezdôdốn elindultak a magyar helyzetet és a lehetséges beavatkozásokat vizsgáló kutatások. A 2000-es évek elején az iskolák több mint $80 \%$-a részt vett prevenciós programokban, míg a 2010-es években mindöszsze 15\% (Paksi, 2019). Ennek ellenére a prevenciós szakma nemzetközileg is mérhetó fejlődése tovább folytatódott. A legfontosabb szakpolitikai ajánlások - minôségbiztosítási standardok - Magyarországon az univerzális és a szelektív prevencióval, illetve a színtér-specifikus (iskola, közösség) megelôzô, egészségfejlesztô programokkal kapcsolatban fogalmazódtak meg (Felvinczi, 2006, 2019; Felvinczi és Nyírády, 2009; Felvinczi, Sebestyén, Mutatayi és Malczewski, 2015a, 2015b, 2015c; Gerevich és Bácskai, 1995; Nădășan és mtsai, 2016; Paksi, Demetrovics és Czakó, 2002a, 2002b; Paksi és mtsai, 2006; Urbán, 2007).

\section{Speciális populációk - leszakadók, szegregátum, táncos szórakozóhelyek, pláza}

A problémás pszichoaktívanyag-használat egyes marginális, leszakadó társadalmi csoportokban fokozott. Ilyen kutatások már az 1980-as években is elindultak (Gerevich és Zseni, 1981; Rácz, 1989). A 90-es évektôl kezdôdôen a budapesti heroinhasználók élettörténeti elemzése az áldozati, az ágensszerepet tagadó vagy felfüggesztô narratívák tanulmányozását tette lehetôvé. Ez a vizsgálat kapcsolódott az MTA Pszichológiai Intézet narratív pszichológiai kutatásaihoz (Rácz, 2009). A 2010-es években egy tûcsereközpont kliensei az injekciós magatartáshoz társuló eszközhasználat (közös a tû- és fecskendôhasználat) és annak normarendszerének feltárását tették lehetôvé (Gyarmathy és mtsai, 2016; Rácz és mtsai, 2016). A túcsereprogramban azonosították elôször az új pszichoaktív szerek 2010-es megjelenésekor kialakuló szerváltás jelenségét (Csák, Demetrovics és Rácz, 2013; Rácz, Csák és Lisznyai, 2015).

A 2010-es évek végén városi és vidéki szegregátumokban vizsgálták az új pszichoaktív szerek (ÚPSZ) használatát. A társadalmi egyenlôtlenségek, a segítô intézményekhez való hozzáférés akadályozottsága, a stigmatizációs folyamatok a könnyen és olcsón beszerezhetô, gyorsan, és sokszor súlyos pszichopatológiai tüneteket okozó szintetikus 
kannabinoid receptor agonista anyagok terjedésének kedveztek. A kvalitatív vizsgálatok alkalmasak voltak arra, hogy feltárják a szerhasználat „túlélést” segítô szerepét (Csák, Szécsi, Kassai, Márványkövi és Rácz, 2020).

Egyes színtereken, pl. zenés-táncos szórakozóhelyeken speciális kockázatokat jelentố szerhasználat fordul elô. Az itt elinduló kutatómunka elsố fázisában fel kellett venni e csoportokkal a kapcsolatot, ami speciális elérési technikák kialakítását igényelte (pl. utcai elérés, privilegizált hozzáférés, társasháló-alapú megkeresés). Az 1990-2000-es évek fordulóján a zenés-táncos szórakozóhelyeken tapasztalt polidroghasználat összefüggésben állt ennek az ifjúsági kultúrának az érték- és normarendszerével, az egyének szerhasználata pedig a szubkultúrán belüli karrierjük lépcsôfokaival (Demetrovics, 1998, 2000, 2001; Rácz, 2008). A kutatások színtérspecifikus ártalomcsökkentô segítôprogramokat indukáltak (pl. biztonságosabb táncolás, partiszerviz, bulisegélyprogramok) (Demetrovics és Pelle, 2000). E kutatásokhoz kapcsolódóan speciális színtereken folyó prevenciós kutatások eredményességvizsgálata is lezajlott (Demetrovics, Paksi és Dúll, 2009). A kutatások tanulsága, hogy a szelektív prevenciót minél közelebb kell vinni a kockázati csoportokhoz; a szolgáltatások tervezésénél az ô értékeiket és normáikat is figyelembe kell venni, továbbá be kell vonni tagjaikat.

A veszélyeztetett fiatalok közül Magyarországon a gyermekvédelmi gondoskodásban élôk (Elekes és Paksi, 2005; Örkényi és mtsai, 2003) és a roma fiatalok (Ritter, 2005) körében készültek a drogfogyasztás elterjedtségének és rizikótényezőinek feltárására irányuló kutatások. A fogvatartottak körében ez idáig három alkalommal, először 1997-ben (Elekes és Paksi, 1997), majd 2004-ben (Elekes és Paksi, 2004) és 2008-ban (Paksi és Arnold, 2010) készült kvantitatív drogepidemiológiai adatfelvétel. A hajléktalanpopuláció drogérintettségét, droghasználati szokásait - Európában egyedülálló módon - reprezentatív mintán vizsgáló kutatás elôször 2007-ben a fôvárosban (Paksi, Gurály, Arnold, Schmidt és Breitner, 2008), majd 2017-ben országos mintán (Paksi, Magi és Gurály, 2021) készült a „Február Harmadika (F3)” kutatássorozat adatfelvételeihez kapcsolódva.

A szerhasználati motivációk, fokozott újdonságkeresés miatt kockázati helyzetben levô serdülôk vizsgálata, a kockázati faktorok azonosítása történt ebben az idôszakban, nemzetközileg is számottevô eredményekkel (Benschop és mtsai, 2020; Urbán, 2010; Urbán, Kökönyei és Demetrovics, 2008; Urbán, Magyaródi és Rigó, 2011).

\section{Új szintetikus szerek}

A 2010-es évektôl az Európa-szerte megjelenô új szintetikus szerek (ÚPSZ) népegészségügyi szempontból kiemelt jelentôségúek voltak (Demetrovics, 2003b, 2003c). A hazai kutatások a szerek hatását, tüneteit, a szerhasználat kialakulását, speciális kockázati tényezôk feltárását célozták (Kapitány-Fövény, Ferenci, Demetrovics és Sulyok, 2021; Kapitány-Fövény és mtsai, 2013; Kapitány-Fövény, Mervó, Corazza és mtsai, 2015; Kapitány-Fövény, Mervó, Kertész és mtsai, 2015; Kapitány-Fövény, Zacher, Posta és Demetrovics, 2017). Kérdés volt, hogy vajon új társadalmi csoportok léptek be a fogyasztók közé, vagy pedig a korábbi szerhasználók váltottak át az új szerekre. Fennállnak-e speciális demográfiai (serdülôkor), társadalmi vagy egyéni jellemzôk? Koráb- 
ban említettük a szegregált társadalmi csoportokban megjelenô ÚPSZ-használatot mint egy speciális társadalmi csoport szerhasználatát, de említhetjük a helyettesítô kezelésben részt vevô szerhasználókat is, akik szintén veszélyeztetettek az ÚPSZ tekintetében. Ugyanakkor az utóbbi csoport a kutatások számára könnyebben elérhetô, így az ÚPSZ-hatás olyan összetevôi is vizsgálhatók, amelyek máshol nem (pl. KapitányFövény, Farkas és mtsai, 2017).

Az ÚPSZ-oknál a használat élménye is feltárandó volt, hiszen ismeretlen szerek jelentek meg (ha a kémiai összetétel és így a hatás várható iránya ismert is volt). Az élmény és az énkép, az identitás közötti kapcsolat is kérdéses volt, amit az interpretatív fenomenológiai analízis módszerével lehetett megvizsgálni (Kassai, Pintér, Rácz, Böröndi és mtsai, 2017; Kassai, Pintér, Rácz, Erdôsi és mtsai, 2017). Így választ kereshettek arra a kérdésre, hogy van-e az ÚPSZ-szerhasználói identitás és a drogos karrier között kapcsolat. A segítôintézmény-rendszer vonatkozásában a kutatások az opiátkorszak utáni ÚPSZ-korszakot tártak fel, ahol a korábbi, az opiáthasználók igényeire szabott terápiás és ártalomcsökkentô lehetôségek már nem hatékonyak (pl. tûcsereprogramok, helyettesítô és fenntartó kezelés, sorstárs- - korábbi heroinfüggô - alapú terápiás közösségek, felépülési modell).

\section{Viselkedési addikciók}

A magyarországi addiktológiai kutatás igen korán, már az ezredforduló legelején bekapcsolódott a viselkedési addikciók kutatásába (Nyikos, Szeredi és Demetrovics, 2001), sốt - elsốdlegesen az ELTE-n folyó kutatásoknak köszönhetôen - annak egyik meghatározó központja lett, hozzájárulva ahhoz az elmúlt két évtizedben lezajló szemléletváltozáshoz, amely a viselkedési addikciók integrációját eredményezte a korábban elsôdlegesen vagy akár kizárólagosan a pszichoaktívszer-használattal kapcsolatos problémákra szorítkozó addiktológiában (Demetrovics és Griffiths, 2012). Bár az egyes jelenségek addikcióként történô értelmezése már a 2000-es évek elôtt is felbukkant a szakmai diskurzusokban mind hazánkban (Kelemen, 1994; Németh és Gerevich, 2000; Rácz, 1999; Túry, 1995), mind pedig a nemzetközi színtéren (Griffiths, 1996, 2000), az egységes szemlélet valójában szinte teljes egészében hiányzott, sôt mára sem alakult ki egyértelmúen.

A hazai kutatók és kutatások jelentôsen hozzájárultak ezen szemléletmód-változás alakulásához (Király és Demetrovics, 2017; Király, Sleczka és mtsai, 2017; Müller és mtsai, 2019), illetve emellett számos meghatározó kutatást végeztek az egyes viselkedési addikciókkal kapcsolatosan, elsôdlegesen a problémás internethasználat (Demetrovics és mtsai, 2016; Demetrovics, Szeredi és Rózsa, 2008; Laconi és mtsai, 2019), a problémás videójáték-használat, a kényszeres vásárlás (Weinstein, Maraz, Griffiths, Lejoyeux és Demetrovics, 2016), a testedzésfüggôség (Mónok és mtsai, 2012), a szerencsejáték-használati zavar (Kun, Balázs, Arnold, Paksi és Demetrovics, 2012), a hiperszexualitás, a problémás pornóhasználat, a problémás közösségimédia-használat, a munkafüggóség és néhány egyéb viselkedés terén. Ezen kutatások egyrészt mérôeszközök, súlyosságbecslô skálák kialakítására (amelyek közül több ma már széles körben elterjedt, számos nyelvre lefordított eszközzé vált), epidemiológiai adatgyújtésre, vala- 
mint a pszichológiai prediktorok és komorbid tüneti állapotok feltárására irányultak (1. pl. Bányai és mtsai, 2017; Bôthe, Baumgartner és mtsai, 2020; Bôthe, Tóth-Kiraly, Bella és mtsai, 2020; Bôthe, Tóth-Kiraly, Griffiths és mtsai, 2020; Demetrovics és mtsai, 2012; Demetrovics és mtsai, 2011; Király és mtsai, 2019; Király, Tóth, Urbán, Demetrovics és Maraz, 2017; Maraz, Hende, Urbán és Demetrovics, 2017).

\section{Hatékonyságvizsgálatok}

A heroinhasználat elterjedése olyan addiktológiai terápiás eljárások bevezetését igényelte Magyarországon, amelyek addig nem álltak rendelkezésre, és sok esetben a közvélemény, de akár egyes szakembercsoportok részérôl is ellenállást váltottak ki. Ilyen volt az 1990-es évek eleje óta az opiáthasználók helyettesítő, illetve fenntartó kezelésének (metadonnal, Suboxonnal) ismertetése és vizsgálata (Demetrovics, Farkas és mtsai, 2009; Demetrovics, Honti, Csorba és Szemelyácz, 2001; Demetrovics, Honti, Szemelyácz és Csorba, 2001; Honti, Szemelyácz, Demetrovics és Csorba, 2001; Petke és mtsai, 2011; Petke és mtsai, 2012). Az addiktológiai pszichológia szempontjából különösen érdekesek azok a vizsgálatok, melyek e speciális populáción teszik lehetôvé pl. a negatív életeseményekkel való megküzdés vagy az öngyógyszerelési modell tanulmányozását (Kapitány-Fövény, Kiss és mtsai, 2020). A prevenciós programok hatékonyságvizsgálatait korábban említettük.

\section{Kvalitatív drogkutatások}

A marginalizált társadalmi csoportok szerhasználatával kapcsolatos kutatások az 1980-as években indultak, akkor még a városi etnográfia és a szociálpszichiátria alá sorolt módszertannal (Rácz, 1989). Az 1990-es években születtek Kelemen Gábor a kvalitatív módszertant a szociális konstruktivizmus felól megalapozó tanulmányai. Az 1990-es évektôl már kvalitatív módszerekkel folytak kutatások: elsôsorban az elérést, a kapcsolatfelvételt célzó módszerekkel, illetve a résztvevô megfigyelést végzô kutató kutatói pozíciójának feltárásával. E kutatások kapcsolódtak a heroinhasználók injekciós szokásait feltáró és a jelenségre adott ellátási válasz (ártalomcsökkentés) tanulmányozásához, majd az ÚPSZ megjelenéséhez. A 2010-es években a kvalitatív pszichológiai módszerek fejlesztése került a középpontba, az interpretatív fenomenológiai analízis hazai adaptációjával (Rácz, Pintér és Kassai, 2017). A módszer az élmény- és identitásszervezôdés feltárására, illetve e két jelenség összekapcsolt fejlődésének vizsgálatára alkalmas. Az életút-narratívák vizsgálata hiányos ágenciájú, áldozati narratívák azonosítását teszi lehetôvé, vagy a felépülés és a segítés összekapcsolódásának vizsgálatát az addiktológia területén dolgozó tapasztalati szakértôk esetében (Rácz, Csák és Lisznyai, 2015; Rácz, Kassai és mtsai, 2015). A kezelés-felépülés során pedig a keresô-felfedezô típusú betegségnarratíva jelenik meg (Rácz, 2006).

A Rácz József által vezetett Kvalitatív Pszichológia Kutatócsoport (ELTE Pszichológiai Intézet) fó érdeklôdési területe az addiktológiai pszichológia, ahogy azt az ÚPSZvagy a szegregátumkutatásoknál láttuk. 
A mérôeszközök fejlesztése érinti addiktológiai problémák beavatkozásszempontú mérését, a szúrést és az állapotfelmérést, a veszélyeztetettség meghatározását, a diagnosztikus munkát, valamint az epidemiológiai kutatásokat. A méróeszköz-fejlesztés tétje, hogy sikerül-e olyan mérôeszközöket kifejleszteni, amelyek segítségével eldönthetô, hogy egy addikciós jelenség mikor minôsül, mikor minôsíthetô betegségként, illetve orvosi, pszichológiai beavatkozást igénylô állapotként. A mérôeszköz-fejlesztés az addikciós problémák bizonyítékon alapuló kezelésének, illetve a terápiás protokollok kidolgozásának is az alapját képezi. A beavatkozások tervezéséhez ismernünk kell, hogy a társadalom egyes nagyobb csoportjaiban mekkora az addikciós problémákkal küzdôk köre; sikerül-e ezekhez az „adatokhoz” kockázati és védôfaktorokat, motivációs állapotokat rendelni, így egy hatékony intervenciós rendszert kialakítani.

\section{SZAKMAI KÖZÉLETI FEJLEMÉNYEK}

Az elsô szakmai ernyôszervezetek (Magyar Narkológiai Társaság, Drogambulanciák Szakmai Szövetsége Tanácsa) már 1988-ban megszülettek, de az addiktológia területét országosan átfogó Magyar Addiktológiai Társaság megalakulása 1994-ben történt meg. Az ekkor még és múködése elsố tíz évében elsôdlegesen orvosi társaság a 2000-es évek elejétôl-közepétôl fokozatosan nyitott a szociális szakmák, illetve a pszichológiai szakma felé, s vált interdiszciplináris tudományos-szakmai társasággá. Az 1994 óta évi-kétévi rendszerességgel megrendezett országos kongresszusok az addiktológia szakma meghatározó rendezvényeivé váltak, de ezek mellett a társaság számos kisebb továbbképzést, szakmai konferenciát is rendezett az elmúlt évtizedekben.

A hazai addiktológia kibontakozása elsố pillanatától kereste és erósítette nemzetközi kötôdéseit, s jelenleg kifejezetten erôsen beágyazott a nemzetközi kutatási-együttmúködési rendszerekbe. A Magyar Addiktológiai Társaság tagja a hasonló szervezeteket tömörítô nemzetközi ernyôszervezetnek (International Confederation of Alcohol, Tobacco and other Drug [ATOD] Research Associations; ICARA). A viselkedési addikciókkal foglalkozó elsố nemzetközi konferencia ( $1^{\text {st }}$ International Conference on Behavioral Addictions) 2013-ban Budapesten került megrendezésre, s a viselkedési addikciók kutatására létrehozott nemzetközi szervezet (International Society for the Study of Behavioral Addictions, 2016) alapító elnöke Demetrovics Zsolt. Hasonlóképp Budapesten, egy nemzetközi pályázati együttmúködés keretében került megrendezésre az elsô, az új szintetikus szerekkel foglalkozó nemzetközi kongresszus (First International Conference on Novel Psychoactive Substances) 2012 tavaszán. Szintén kiemelendô, hogy 2005-ben szintén Budapest adhatott otthont az egyik legjelentôsebb nemzetközi addiktológiai kongresszusnak (48th International ICAA Conference on Dependences). Magyarország a kezdetektôl, 1995-tôl tagja a nemzetközi ESPAD (European School Survey Project on Alcohol and other Drugs) kutatásnak Elekes Zsuzsanna és Paksi Borbála révén, illetve mintegy három és fél évtizede csatlakozott, és azóta aktív résztvevôje a szintén nemzetközi HBSC Health Behaviour in School-Aged Children kutatásnak, kezdetben Aszmann Anna (Országos Gyermek- 
jóléti Intézet), jelenleg Németh Ágnes (ELTE Klinikai Pszichológia és Addiktológia Tanszék) vezetésével.

Az addiktológia megerôsödése tekintetében kiemelendô a képzési rendszer kialakítása. A 80-as évek végén, 90-es évek elején induló rövidebb tanfolyamokat viszonylag hamar váltotta a formális, egyetemekhez rendelt képzési-szakképzési rendszer kialakítása. Az orvosi területen az addiktológus szakvizsga bevezetése (1994), pszichológus szakterületen a klinikai addiktológiai szakpszichológus képzés elindítása, az egyéb diplomások számára pedig az addiktológiai konzultáns képzés (1997) jelentett továbbképzési lehetôséget.

A szakmai folyóiratok terén az Alkohológia helyét 1993-tól a Buda Béla szerkesztette Szenvedélybetegségek (Addictologia Hungarica) vette át, amelyet aztán 2003-tól Rácz József szerkesztett Addiktológia (Addictologia Hungarica) néven, megújult formában, akkor már a Magyar Addiktológiai Társaság lapjaként (kiadó: Interdiszciplináris Addiktológiai Fórum Tudományos és Ismeretterjesztő Kht.). A folyóirat 2010-es megszúnése szomorú fejlemény a hazai addiktológia történetében, de egyben a terület jelentôs fejlôdését és nemzetköziesedését is jelzi. A területen tudományosan publikáló hazai szakemberek túlnyomó többsége ugyanis a 2010-es években már dominánsan nemzetközi lapokban közölte eredményeit, s ily módon az Addiktológia egyre kevésbé számíthatott magyar nyelvú kéziratokra. A magyar nyelvú addiktológiai közlemények ma elsôsorban a Psychiatria Hungarica, a Magyar Pszichológiai Szemle, a Mentálhigiéné és Pszichoszomatika vagy a Neuropsychopharmacologia Hungarica hasábjain jelennek meg, ritkábban társadalomtudományi, szociológiai folyóiratokban.

A folyóiratok tekintetében kiemelendő, hogy hazai alapítású (ELTE Pedagógiai és Pszichológiai Kar, 2010, alapító fôszerkesztô: Demetrovics Zsolt) és az Akadémiai Kiadó gondozásában jelenik meg az addiktológia elsố három legjelentôsebb szakmai folyóirata között rangsorolt Journal of Behavioral Addictions címú folyóirat (Q1 besorolású, impakt faktora: 6,756).

\section{ZÁRÓ GONDOLATOK}

Az addiktológia hazai fejlôdése a fentiek alapján igazi sikerterületnek mondható az elmúlt mintegy harminc év vonatkozásában. Több kutatócsoport nemzetközi szinten is meghatározó eredményeket mutat fel, kutatóink részét képezik a nemzetközi kutatás fốáramának, s képviseltetik magukat sikeres nemzetközi pályázatok résztvevôiként, jelentôs folyóiratok szerkesztôiként és egyéb meghatározó pozíciókban. Mindemellett meg kell azonban említeni a szélesebb értelemben vett addiktológiai kutatóhelyek és egykor a nemzeti kábítószerügyi koordinációhoz tartozó intézmények megszúnését, a szakemberek elvándorlását is. A tudományos sikerek mellett a klinikai addiktológiai ellátás fejlődése jelentôs hátrányokat szenved, a 2010-es évektôl kezdôdôen a prevenciós törekvések támogatása nagymértékben csökkent, az ártalomcsökkentés területét pedig a forráshiány mellett többször politikai támadások is érték. Mindez kettôs képet mutat, azaz a tudományos sikeresség mellett a területet a drogpolitika visszahúzódása, s ennek következtében a terület érdekérvényesítésének csökkenése, s ily módon a terápiás és prevenciós terület deficitje jellemzi. 


\section{KÖSZÖNETNYILVÁNÍTÁS}

A tanulmány elkészítését a Nemzeti Kutatási, Fejlesztési és Innovációs Hivatal támogatta (KKP126835; KP135629).

\section{IRODALOM}

Andó, B., Rozsa, S., Kurgyis, E., Szkaliczki, A., Demeter, I., Szikszay, P., et al. (2014). Direct and indirect symptom severity indicators of alcohol dependence and the personality concept of the biosocial model. Subst Use Misuse, 49(4), 418-426. DOI: 10.3109/10826084.2013.841250

Andorka, R. (1987). Történet, demográfia és társadalmi különbségek. Info-Társadalomtudomány, 2, 17-28.

Andorka, R. (1988). Az alkoholizmus magyarországi kutatása. Münnich, I. (Ed.), Tanulmányok a társadalmi beilleszkedési zavarokról (pp. 12-15). Budapest: Kossuth.

Andorka, R. (1994). Alkoholizmus és alkoholpolitika. Münnich, I., \& Moksony, F. (Eds), Devianciák Magyarországon (pp. 266-297). Budapest: Közélet.

Andorka, R., Buda, B., Donga, K., György, I., Kolozsi, B., Moksony, F., et al. (1986). Társadalmi beilleszkedési zavarok Magyarországon. Budapest: Kossuth.

Bácskai, E., \& Gerevich, J. (1997). Ifjúság és drogfogyasztás. Budapest: Animula.

Bácskai, E., \& Gerevich, J. (2006). Kokainprobléma Magyarországon. Budapest: Medicina.

Bányai, F., Zsila, Á., Király, O., Maraz, A., Elekes, Z., Griffiths, M. D., et al. (2017). Problematic Social Media Use: Results from a Large-Scale Nationally Representative Adolescent Sample. PLOS One, 12(1), e0169839. DOI: 10.1371/journal.pone.0169839

Benschop, A., Urbán, R., Kapitány-Fövény, M., Van Hout, M. C., Dąbrowska, K., Felvinczi, K. et al. (2020). Why do people use new psychoactive substances? Development of a new measurement tool in six European countries. Journal of Psychopharmacology, 34, 600-611.

Bôthe, B., Baumgartner, C., Schaub, M. P., Demetrovics, Zs., \& Orosz, G. (2020). Hands-off: Study protocol of a two-armed randomized controlled trial of a web-based self-help tool to reduce problematic pornography use. Journal of Behavioral Addiction, 9(2), 433-445. DOI: 10.1556/2006.2020.00037

Bôthe, B., Tóth-Kiraly, I., Bella, N., Potenza, M. N., Demetrovics, Zs., \& Orosz, G. (2020). Why do people watch pornography? The motivational basis of pornography use. Psychology of Addictive Behaviors, 35(2), 172-186. DOI: 10.1037/adb0000603

Bôthe, B., Tóth-Kiraly, I., Griffiths, M. D., Potenza, M. N., Orosz, G., \& Demetrovics, Zs. (2020). Are sexual functioning problems associated with frequent pornography use and/or problematic pornography use? Results from a large community survey including males and females. Addictive Behaviors, 112, 106603. DOI: 10.1016/j.addbeh.2020.106603

Buda, B. (1981). Pszichoterápia. Budapest: Gondolat.

Buda, B. (1992). Az alkohológia új távlatai - Utak az alkoholproblémák megértéséhez, megelôzéséhez és korai kezelésbevételéhez. Budapest: Alkoholizmus Elleni Bizottság.

Buda, B. (1995). Szenvedélyeink - Megelózés, felismerés, rehabilitálás. Budapest: SubRosa.

Csák, R., Demetrovics, Zs., \& Rácz, J. (2013). Transition to injecting 3,4-methylene-dioxy-pyrov alerone (MDPV) among needle exchange program participants in Hungary. Journal of Psychopharmacology, 27(6), 559-563. DOI: 10.1177/0269881113480987

Csák, R., Szécsi, J., Kassai, S., Márványkövi, F., \& Rácz, J. (2020). New psychoactive substance use as a survival strategy in rural marginalised communities in Hungary. International Journal of Drug Policy, 85, 102639. DOI: https://doi.org/10.1016/j.drugpo.2019.102639 
Csibi, S., Griffiths, M. D., Cook, B., Demetrovics, Zs., \& Szabó, A. (2018). The psychometric properties of the smartphone application-based addiction scale (SABAS). International Journal of Mental Health and Addiction, 16(2), 393-403.

Demetrovics, Zs. (1998). Drog és Disco Budapesten. Táncos szórakozóhelyeket látogató fiatalok szociodemográfiai jellemzôi és drogfogyasztási szokásai. Budapest: Budapesti Szociális Forrásközpont.

Demetrovics, Zs. (2000). A szintetikus drogok világa. Diszkódrogok, drogfogyasztók, szubkultúrák. Budapest: Animula.

Demetrovics, Zs. (2001). Droghasználat Magyarország táncos szórakozóhelyein. Vol. 1. Budapest: L'Harmattan.

Demetrovics, Zs. (2003a). Ártalomcsökkentô drogpolitika és ártalomcsökkentô programok Magyarországon: Helyzetkép - 2003. In Ritter, I., \& Felvinczi, K. (Eds), Jelentés a magyarországi kábitószerhelyzetról (pp. 181-186). Budapest: Gyermek-, Ifjúsági és Sportminisztérium.

Demetrovics, Zs. (2003b). Szintetikus drogok kockázatfelmérése: a ketamin, a GHB és a 4-MTA. Addictologia Hungarica, 2(1), 93-104.

Demetrovics, Zs. (2003c). Szintetikus drogok kockázatfelmérése: a PMMA. Addictologia Hungarica, 2(3-4), 431-437.

Demetrovics, Zs. (2007a). Az addiktológia alapjai I. Budapest: ELTE Eötvös.

Demetrovics, Zs. (2007b). Drog, család, személyiség. Különbözố típusú drogok használatának személyiségpszichológiai és családi háttere. Budapest: L’Harmattan.

Demetrovics, Zs. (2007c). A droghasználat funkciói. Budapest: Akadémiai.

Demetrovics, Zs. (2009a). Az addiktológia alapjai II. Budapest: ELTE Eötvös.

Demetrovics, Zs. (2009b). Az addiktológia alapjai III. Budapest: ELTE Eötvös.

Demetrovics, Zs. (2010). Examples of the interaction between researchers and policy-makers from 16 countries. In Muscat, R. (Ed.), Research and policy (pp. 21). Strasbourg: Council of Europe.

Demetrovics, Zs. (2014). Viselkedési addikciók: spektrumszemléletú kutatások. (Doctor of the Hungarian Academy of Sciences) Budapest: ELTE.

Demetrovics, Zs., Farkas, J., Csorba, J., Németh, A., Mervó, B., Szemelyácz, J., et al. (2009). Early experience with Suboxone maintenance therapy in Hungary. Neuropsychopharmacologia Hungarica, 11(4), 249-257.

Demetrovics, Zs., \& Griffiths, M. D. (2012). Behavioral addictions: Past, present and future. Journal of Behavioral Addictions, 1(1), 1-2.

Demetrovics, Zs., Honti, J., Csorba, J., \& Szemelyácz, J. (2001). A szubsztitúciós metadon kezelés I. Történeti áttekintés. Psychiatria Hungarica, 16(1), 57-69.

Demetrovics, Zs., Honti, J., Szemelyácz, J., \& Csorba, J. (2001). A szubsztitúciós metadon kezelés III. Hatékonyság. Psychiatria Hungarica, 16(1), 80-99.

Demetrovics, Zs., Király, O., Koronczai, B., Griffiths, M. D., Nagygyörgy, K., Elekes, Z., et al. (2016). Psychometric Properties of the Problematic Internet Use Questionnaire Short-Form (PIUQ-SF-6) in a Nationally Representative Sample of Adolescents. PLoS One, 11(8).

Demetrovics, Zs., \& Kun, B. (2010). Az addiktológia alapjai IV. Viselkedési függóségek. Budapest: ELTE Eötvös.

Demetrovics, Zs., \& Kun, B. (2011). Integrált addiktológiai ellátások terjesztése. Budapest: Nemzeti Család- és Szociálpolitikai Intézet.

Demetrovics, Zs., Paksi, B., \& Dúll, A. (2009). Pláza, ifjúság, életmód: Egészségmagatartás vizsgálatok a fiatalok körében. Budapest: L'Harmattan.

Demetrovics, Zs., \& Pelle, A. (2000). „Biztonságos szórakozóhely” program. Ajánlás valamint elméleti és jogi háttéranyag a táncos szórakozóhelyek biztonságos üzemeltetéséhez. Addictologia Hungarica, 8, 433-441. 
Demetrovics, Zs., Szeredi, B., \& Rózsa, S. (2008). The three-factor model of internet addiction: the development of the Problematic Internet Use Questionnaire. Behavior Research Methods, 40(2), 563-574.

Demetrovics, Zs., Urbán, R., Nagygyörgy, K., Farkas, J., Griffiths, M. D., Pápay, O., et al. (2012). The development of the problematic online gaming questionnaire (POGQ). PloS One, 7(5), e36417.

Demetrovics, Zs., Urbán, R., Nagygyörgy, K., Farkas, J., Zilahy, D., Mervó, B., et al. (2011). Why do you play? The development of the motives for online gaming questionnaire (MOGQ). Behavior Research Methods, 43(3), 814-825.

Elekes, Z. (2009). Egy változó kor változó ifjúsága: fiatalok alkohol-és egyéb drogfogyasztása Magyarországon, ESPAD 2007. Budapest: L'Harmattan.

Elekes, Z. (2012). Az ifjúkori drogfogyasztás epidemiológiája. Egészségkárositó magatartások elterjedtsége és társadalmi-demográfiai jellemzôi középiskolások körében végzett kutatások alapján. Budapest: Magyar Tudományos Akadémia.

Elekes, Z., Arnold, P., \& Bencsik, N. (2020). Iskolások egészségkárositó magatartása 25 év távlatában: A 2019. évi ESPAD kutatás magyarországi eredményei. Budapest: Budapesti Corvinus Egyetem.

Elekes, Z., \& Paksi, B. (1994). Adalékok a magyarországi drogfogyasztás alakulásához. In Münnich, I., \& Moksony, F. (Eds), Devianciák Magyarországon (pp. 308-322). Budapest: Közélet.

Elekes, Z., \& Paksi, B. (1996). A magyarországi középiskolások alkohol-és drogfogyasztása. ESPAD The European School Survey Project on Alcohol and Drugs 1995. Budapest: Népjóléti Minisztérium.

Elekes, Z., \& Paksi, B. (1997). Szabadságvesztés büntetést töltók kábítószer-fogyasztással kapcsolatos rizikócsoportjainak feltárása (pp. 1-112). Budapest: Büntetés-végrehajtási Szakkönyvtár.

Elekes, Z., \& Paksi, B. (2000). Drogok és fiatalok: középiskolások droghasználata, alkoholfogyasztása és dohányzása az évezred végén Magyarországon. ISMertetô 8. Budapest: ISM.

Elekes, Z., \& Paksi, B. (2004). A jogerôsen fogvatartottak kábitószer-és egyéb szenvedélyszer-használata. Budapest: Büntetés-végrehajtás Országos Parancsnoksága.

Elekes, Z., \& Paksi, B. (2005). A gyermekvédelmi gondoskodásban részesüló fiatalok alkohol- és egyéb drogfogyasztása. Kapocs, 4(5).

Erdôs, M. B., Bognár, A., Borda, V., Brettner, Z., Kelemen, G., Madácsy, J., et al. (2018). Az addiktológiai ellátórendszer vizsgálata: Kutatási zárójelentés. Szociális Szemle, 11(1-2), 1-289.

Erdôs, M. B., \& Kelemen, G. (2015). A terápiás közösségek értékelésének javasolt modellje. Szociális Szemle, 8(1-2), 220-234.

Felvinczi, K. (2006). A család szerepe a drogprevencióban. In Bíró, J. (Ed.), Biopolitika-drogprevenció. Tanulmányok a kábítószer-fogyasztás megelôzéséról. Budapest: L'Harmattan - ELTE Társadalomtudományi Kar.

Felvinczi, K. (2019). Minôségfejlesztési törekvések a prevenció területén a világban. Educatio, $28(3), 459-472$.

Felvinczi, K., \& Nyírády, A. (2009). Drogpolitika számokban. Budapest: L’Harmattan - Nemzeti Drogmegelózési Intézet.

Felvinczi, K., Sebestyén, E., Mutatayi, C., \& Malczewski, A. (2015a). EDPQS Toolkit 1: Selecting quality drug prevention initiatives for funding and support (Funding \& Decision-Making Toolkit). Assessment Quality Criteria Checklist. Liverpool: Centre for Public Health.

Felvinczi, K., Sebestyén, E., Mutatayi, C., \& Malczewski, A. (2015b). EDPQS Toolkit 1: Selecting quality drug prevention initiatives for funding and support (Funding \& Decision-Making Toolkit). Policy Guide - Part 1: Challenges in selecting high quality prevention initiatives. Liverpool: Centre for Public Health.

Felvinczi, K., Sebestyén, E., Mutatayi, C., \& Malczewski, A. (2015). EDPQS Toolkit 1: Selecting quality drug prevention initiatives for funding and support (Funding \& Decision-Making Toolkit). 
Policy Guide - Part 2: Key issues for promoting high quality in drug prevention. Liverpool: Centre for Public Health.

Gerevich, J. (1988). A hazai drogproblémák és kezelésük. In Baló, G., \& Lipovecz, I. (Eds), Tények könyve (pp. 509-511). Budapest: Computerworld Informatika Kft.

Gerevich, J. (1989). Közösségi mentálhigiéné. Budapest: Animula.

Gerevich, J. (1992). A kábitószer kihívása. Budapest: Gondolat.

Gerevich, J., \& Bácskai, E. (1995). The Development and Prevention of Drug Use. Budapest: Akadémia.

Gerevich, J., \& Bácskai, E. (2012). Korszerü addiktológiai mérômódszerek. Budapest: Semmelweis.

Gerevich, J., \& Bácskai, E. (2017). Agresszió, öngyilkosság, addikció. Budapest: Noran Libro.

Gerevich, J., Bácskai, E., \& Rózsa, S. (2003). A drogambulanciák múködése és hatékonysága. Budapest: Animula.

Gerevich, J., \& Zseni, A. (1981). Serdülókori öndestruktív tendenciák és „ellenkultúra”. Alkohol, I2. 249-251.

Griffiths, M. D. (1996). Behavioural addictions: An issue for everybody? Journal of Workplace Learning, 8, 19-25.

Griffiths, M. D. (2000). Does Internet and Computer „Addiction” Exist? Some Case Study Evidence. Cyberpsychology and Behavior, 3, 211-218.

Griffiths, M. D., King, D. L., \& Demetrovics, Zs. (2014). DSM-5 internet gaming disorder needs a unified approach to assessment. Neuropsychiatry, 4(2), 1-4.

Griffiths, M. D., Van Rooij, A. J., Kardefelt-Winther, D., Starcevic, V., Király, O., Pallesen, S., et al. (2016). Working towards an international consensus on criteria for assessing Internet gaming disorder: A critical commentary on Petry et al.(2014). Addiction, 111(1), 167.

Gyarmathy, V. A., Csák, R., Bálint, K., Bene, E., Varga, A. E., Varga, M., et al. (2016). A needle in the haystack-the dire straits of needle exchange in Hungary. BMC Public Health, 16(1), 1-7.

Honti, J., Szemelyácz, J., Demetrovics, Zs., \& Csorba, J. (2001). A szubsztitúciós metadon kezelés II. Farmakológia és alkalmazás. Psychiatria Hungarica, 16(1), 70-79.

Horváth, Z., Paksi, B., Felvinczi, K., Griffiths, M. D., Demetrovics, Zs., \& Urbán, R. (2019). An empirically based typology of alcohol users in a community sample using latent class analysis. European Addiction Research, 25(6), 293-302.

Kapitány-Fövény, M., Ferenci, T., Demetrovics, Zs., \& Sulyok, M. (2021). Predicting the number of GHB-related toxicologic admissions using Google Trends Data. International Journal of Mental Health and Addiction. DOI: https://doi.org/10.1007/s11469-021-00706-9

Kapitány-Fövény, M., Kertész, M., Winstock, A., Deluca, P., Corazza, O., Farkas, J., et al. (2013). Substitutional potential of mephedrone: An analysis of the subjective effects. Human Psychopharmacology: Clinical and Experimental, 28(4), 308-316.

Kapitány-Fövény, M., Kiss, A., Farkas, J., Kuczora, K. E., Pataki, P., Horváth, J., \& Demetrovics, Zs. (2020). Childhood Trauma, Cognitive Emotion Regulation and Motivation for Behavior Change Among Clients of Opioid Substitution Treatment With and Without Past Year Synthetic Cathinone Use During Therapy. Frontiers in Neuroscience, 14, 37.

Kapitány-Fövény, M., Mervó, B., Corazza, O., Kökönyei, G., Farkas, J., Urbán, R., et al. (2015). Enhancing sexual desire and experience: An investigation on the sexual correlates of gamma-hydroxybutyrate (GHB) use. Human Psychopharmacology: Clinical and Experimental, 30(4), 276-284.

Kapitány-Fövény, M., Mervó, B., Kertész, M., Corazza, O., Farkas, J., Kökönyei, G., et al. (2015). Is there any difference in patterns of use and psychiatric symptom status between injectors and non-injectors of mephedrone? Human Psychopharmacology: Clinical and Experimental, 30(4), 233-243. 
Kapitány-Fövény, M., Urbán, R., Varga, G., Potenza, M. N., Griffiths, M. D., Szekely, A., et al. (2020). The 21-item Barratt Impulsiveness Scale Revised (BIS-R-21): An alternative three-factor model. Journal of Behavioral Addictions, 9(2), 225-246.

Kapitány-Fövény, M., Vagdalt, E., Ruttkay, Z., Urbán, R., Richman, M. J., \& Demetrovics, Zs. (2018). Potential of an interactive drug prevention mobile phone app (once upon a high): questionnaire study among students. JMIR Serious Games, 6(4), e9944.

Kapitány-Fövény, M., Zacher, G., Posta, J., \& Demetrovics, Zs. (2017). GHB-involved crimes among intoxicated patients. Forensic Science International, 275, 23-29.

Kapitány-Fövény, M., Farkas, J., Pataki, P. A., Kiss, A., Horváth, J., Urbán, R., \& Demetrovics, Zs. (2017). Novel psychoactive substance use among treatment-seeking opiate users: The role of life events and psychiatric symptoms. Human Psychopharmacology: Clinical and Experimental, 32(3), e2602.

Kassai, S., Pintér, J. N., Rácz, J., Böröndi, B., Tóth-Karikó, T., Kerekes, K., \& Gyarmathy, V. A. (2017). Assessing the experience of using synthetic cannabinoids by means of interpretative phenomenological analysis. Harm Reduction Journal, 14(1), 1-10.

Kassai, S., Pintér, J. N., Rácz, J., Erdősi, D., Milibák, R., \& Gyarmathy, V. A. (2017). Using interpretative phenomenological analysis to assess identity formation among users of synthetic cannabinoids. International Journal of Mental Health and Addiction, 15(5), 1047-1054.

Kelemen, G. (1994). Az addikciók széles spektruma. Budapest: Országos Alkohológiai Intézet.

Kelemen, G. (2001). Szenvedélybetegség, család, pszichoterápia. Pécs: Pro Pannonia.

Kelemen, G. (2009). A velünk éló szenvedélyek - Szenvedélypolitika és egészségtanulás. Pécs: Pannónia Könyvek.

Kelemen, G. (2011). Átlendülés. Változatok a reflektív klinikai szociális munkához. Budapest: Animula.

King, D. L., Delfabbro, P. H., Potenza, M. N., Demetrovics, Zs., Billieux, J., \& Brand, M. (2018). Internet gaming disorder should qualify as a mental disorder. Australian and New Zealand Journal of Psychiatry, 52(7), 615-617.

Király, O., Bôthe, B., Ramos-Diaz, J., Rahimi-Movaghar, A., Lukavska, K., Hrabec, O., et al. (2019). Ten-Item Internet Gaming Disorder Test (IGDT-10): Measurement invariance and cross-cultural validation across seven language-based samples. Psychology of Addictive Behaviors, 33(1), 91.

Király, O., \& Demetrovics, Zs. (2017). Inclusion of Gaming Disorder in ICD has more advantages than disadvantages: Commentary on: Scholars' open debate paper on the World Health Organization ICD-11 Gaming Disorder proposal (Aarseth et al.). Journal of Behavioral Addictions, 6(3), 280-284.

Király, O., Griffiths, M. D., \& Demetrovics, Zs. (2015). Conceptualization, debates, and controversies. Current Addiction Reports, 2(3), 254-262.

Király, O., Sleczka, P., Pontes, H. M., Urbán, R., Griffiths, M. D., \& Demetrovics, Zs. (2017). Validation of the Ten-Item Internet Gaming Disorder Test (IGDT-10) and evaluation of the nine DSM-5 Internet Gaming Disorder criteria. Addictive Behaviors, 64, 253-260.

Király, O., Tóth, D., Urbán, R., Demetrovics, Zs., \& Maraz, A. (2017). Intense video gaming is not essentially problematic. Psychology of Addictive Behaviors, 31(7), 807.

Kisszékelyi, Ö. (1973). Antiparkinsonos szer (Parkan) mint hallucinogén. Orvosi Hetilap, 15, 855-859.

Kisszékelyi, Ö. (1975). Drogfogyasztás középiskolások körében. Orvosi Hetilap, 15, 846-848.

Kisszékelyi, Ö. (1979). Toxikománia. Budapest: BM Könyvkiadó.

Kovács, I., Demeter, I., Janka, Z., Demetrovics, Zs., Maraz, A., \& Andó, B. (2020). Different aspects of impulsivity in chronic alcohol use disorder with and without comorbid problem gambling. PloS One, 15(1), e0227645. 
Kovács, I., Pribék, I. K., Demeter, I., Rózsa, S., Janka, Z., Demetrovics, Zs., \& Andó, B. (2020). The personality profile of chronic alcohol dependent patients with comorbid gambling disorder symptoms. Comprehensive Psychiatry, 101, 152183.

Kun, B., Balázs, H., Arnold, P., Paksi, B., \& Demetrovics, Zs. (2012). Gambling in Western and Eastern Europe: the example of Hungary. Journal of Gambling Studies, 28(1), 27-46.

Kun, B., Urbán, R., Paksi, B., Griffiths, M. D., Richman, M. J., \& Demetrovics, Zs. (2019). The effects of trait emotional intelligence on adolescent substance use: Findings from a Hungarian representative survey. Frontiers in Psychiatry, 10, 367.

Laconi, S., Urbán, R., Kaliszewska-Czeremska, K., Kuss, D. J., Gnisci, A., Sergi, I., et al. (2019). Psychometric evaluation of the nine-item Problematic Internet Use Questionnaire (PIUQ-9) in nine European samples of internet users. Frontiers in Psychiatry, 10, 136.

Lázár, I., \& Pikó, B. (2012). Orvosi antropológia. Budapest: Medicina.

Levendel, L. (1987). Alkoholbetegek gyógykezelése és gondozása. Budapest: Akadémiai.

Maraz, A., Hende, B., Urbán, R., \& Demetrovics, Zs. (2017). Pathological grooming: Evidence for a single factor behind trichotillomania, skin picking and nail biting. PLoS One, 12(9), e0183806.

Mónok, K., Berczik, K., Urbán, R., Szabó, A., Griffiths, M. D., Farkas, J., et al. (2012). Psychometric properties and concurrent validity of two exercise addiction measures: A population wide study. Psychology of Sport \& Exercise, 13(6), 739-746.

Müller, A., Brand, M., Claes, L., Demetrovics, Zs., De Zwaan, M., Fernández-Aranda, F., et al. (2019). Buying-shopping disorder-is there enough evidence to support its inclusion in ICD-11? CNS Spectrums, 24(4), 374-379.

Nădășan, V., Foley, K. L., Pénzes, M., Paulik, E., Mihăicuță, S.., Ábrám, Z., et al. (2016). The Short-term Effects of ASPIRA: A Web-based, Multimedia Smoking Prevention Program for Adolescents in Romania: A Cluster Randomized Trial. Nicotine \& Tobacco Research, 19(8), 908-915. DOI: https://doi.org/10.1093/ntr/ntw308

Németh, A., \& Gerevich, J. (2000). Addikciók. Budapest: Medicina.

Nyikos, E., Szeredi, B., \& Demetrovics, Zs. (2001). Egy új viselkedéses addikció: Az internethasználat személyiségpszichológiai korrelátumai. Pszichoterápia, 10(3), 168-182.

Országgyúlés (2000). Nemzeti stratégia a kábitószer-probléma visszaszoritására. Budapest.

Örkényi, Á., Aszmann, A., Balogh, Á., Koszonits, R., Kökönyei, G., Németh, Á., et al. (2003). Drogfogyasztás állami gondozott fiatalok körében. Budapest: Ifjúsági, Családügyi, Szociális és Esélyegyenlôségi Minisztérium.

Paksi, B. (2003). Drogok és felnöttek: a tizennyolc év feletti lakosság drogfogyasztása és droggal kapcsolatos gondolkodása az ezredfordulón, Magyarországon. Budapest: L’Harmattan.

Paksi, B. (2019). Magyarországi tendenciák az iskolai prevenció területén. Educatio, 28(3), 441-458.

Paksi, B., \& Arnold, P. (2010). A jogerôsen elítélt fogvatartottak droghasználata. Börtönügyi Szemle, 29(1), 1-23.

Paksi, B., \& Demetrovics, Zs. (2002). A drogprevenciós gyakorlat megismerése. A budapesti középiskolai drogprevenciós programok felmérése és értékelése. Budapest: L'Harmattan.

Paksi, B., \& Demetrovics, Zs. (2011). Drogprevenció és egészségfejlesztés az iskolában. Budapest: L'Harmattan.

Paksi, B., \& Demetrovics, Zs. (2021). Addiktológiai problémák Magyarországon - Helyzetkép a lakossági kutatások tükrében. Budapest: L'Harmattan.

Paksi, B., Demetrovics, Zs., \& Czakó, Á. (2002a). Az iskolai drogprevenciós programok értékelése I. rész. Addictologia Hungarica, 1(1), 15-37.

Paksi, B., Demetrovics, Zs., \& Czakó, Á. (2002b). Az iskolai drogprevenciós programok értékelése II. rész. Addictologia Hungarica, 1(1), 38-49. 
Paksi, B., Demetrovics, Zs., Griffiths, M. D., Magi, A., \& Felvinczi, K. (2020). Estimating and managing the changing methodological parameters of self-report surveys of addictive behavior-based on the waves of the National Survey on Addiction Problems in Hungary. Neuropsychopharmalogia Hungarica, 22(1), 29-42.

Paksi, B., Demetrovics, Zs., Magi, A., \& Felvinczi, K. (2017). Az Országos Lakossági Adatfelvétel az Addiktológiai Problémákról 2015 (OLAAP 2015) reprezentatív lakossági felmérés módszertana és a minta leíró jellemzôi. Neuropsychopharmacologia Hungarica, 19, 55-85.

Paksi, B., Demetrovics, Zs., Nyírády, A., Nádas, E., Buda, B., \& Felvinczi, K. (2006). A magyarországi iskolai drogprevenciós programok jellemzôi. Addictologia Hungarica, 5(1-2), 5-36.

Paksi, B., Gurály, Z., Arnold, P., Schmidt, A., \& Breitner, P. (2008). A drogfogyasztás és hajléktalanság. Addiktológia Hungarica, 2, 101-130.

Paksi, B., Magi, A., \& Gurály, Z. (2021). A hajléktalan emberek pszichoaktív szerhasználata. Esély, 32.

Paksi, B., Rózsa, S., Kun, B., Arnold, P., \& Demetrovics, Zs. (2009). A magyar népesség addiktológiai problémái: az országos lakossági adatfelvétel az addiktológiai problémákról (OLAAP) reprezentatív felmérés módszertana és a minta leíró jellemzői. Mentálhigiéné és Pszichoszomatika, 10(4), 273-300.

Petke, Z., Csorba, J., Mészáros, J., Vingender, I., Farkas, J., Demetrovics, Zs., et al. (2011). Kezelésben maradásra ható tényezôk vizsgálata metadon- és burrenorfine/naloxone terápiában részesülô opiátfüggőóknél. Addictologia Hungarica, 10(1), 5-31.

Petke, Z., Csorba, J., Mészáros, J., Vingender, I., Farkas, J., Demetrovics, Zs., et al. (2012). Buprenorphin/naloxon szubsztitúció alatt álló ópiátfüggốk pszichoszociális tüneteinek változásai hathónapos terápia során. Neuropsychopharmacologia Hungarica, 14(1), 7-17.

Pikó, B. (2000). Fiatalok pszichoszociális egészsége és rizikómagatartása a társas támogatás tükrében. Budapest: Osiris.

Pikó, B. (2002). A deviáns magatartás szociológiai alapjai és megjelenési formái a modern társadalomban. Szeged: JATE Press.

Pikó, B. (2005a). Ifjúság, káros szenvedélyek és egészség a modern társadalomban. Budapest: L'Harmattan.

Pikó, B. (2005b). Lelki egészség a modern társadalomban: pozitíu pszichológia. Budapest: Akadémiai.

Pikó, B. (2006). Orvosi szociológia. Budapest: Medicina.

Pikó, B. (2010). Védófaktorok nyomában. Budapest: L’Harmattan.

Pikó, B. (2013). Fiatalok lelki egészsége és problémaviselkedése a rizikó-és protektív elmélet, a pozitív pszichológia és a társadalomlélektan tükrében. (Doctor of the Hungarian Academy of Sciences) Szeged: SZTE ÁOK.

Rácz, J. (1988a). A drogfogyasztó magatartás. Budapest: Medicina.

Rácz, J. (1988b). A személyiségjogok kérdése a drogfogyasztók terápiájában. In Lévai, M. (Ed.), A jog és a terápia összefüggései a kábitószerfogyasztók kezelésében (pp. 57-66). Budapest: MTA Kriminológiai Társaság.

Rácz, J. (1989). Ifjúsági szubkultúrák és fiatalkori „devianciák”. Budapest: Magyar Pszichiátriai Társaság.

Rácz, J. (1992). Drug use by the members of youth subcultures in Hungary. International Journal of the Addictions, 27(3), 289-300.

Rácz, J. (1999). Addiktológia. Tünettan és intervenciók. Budapest: HIETE.

Rácz, J. (2005). Ártalomcsökkentô drogpolitika. Magyar Tudomány, 8.

Rácz, J. (2006). Kvalitatív drogkutatások: kvalitatív kutatások budapesti droghasználók között. Budapest: L'Harmattan.

Rácz, J. (2008). Az esélyteremtés új útjai: Kortárs és sorstárs segítéssel szerzett tapasztalataink. Budapest: L'Harmattan. 
Rácz, J. (2009). Injekciós droghasználók szociálpszichológiai jellemzôi a körükben végzett kvalitatív kutatások alapján. Budapest: Magyar Tudományos Akadémia.

Rácz, J., Csák, R., \& Lisznyai, S. (2015). Transition from "old" injected drugs to mephedrone in an urban micro segregate in Budapest, Hungary: a qualitative analysis. Journal of Substance Use, 20(3), 178-186.

Rácz, J., Csák, R., Tóth, K. T., Tóth, E., Rozmán, K., \& Gyarmathy, V. A. (2016). Veni, vidi, vici: the appearance and dominance of new psychoactive substances among new participants at the largest needle exchange program in Hungary between 2006 and 2014. Drug and Alcohol Dependence, 158, 154-158.

Rácz, J., Göncz, D., \& Kéthelyi, J. (1984). A Z. téri „csövesek”. Egy szociológiai vizsgálat tapasztalataiból. Világosság, 25(11), 674-682.

Rácz, J., Kassai, S., Pintér, J. N., Benedeczki, P., Dobó-Nagy, Z., Horváth, Z., \& Gyarmathy, V. A. (2015). The therapeutic journeys of recovering helpers-an interpretative phenomenological analysis. International Journal of Mental Health and Addiction, 13(6), 751-757.

Rácz, J., Melles, K., Márványkövi, F., Lencse, M., \& Petke, Z. (2011). Communicating the principle of 'treatment instead of punishment' in Hungary on the basis of an examination of the patients at a drug outpatient clinic. Drugs: Education, Prevention and Policy, 18(3), 207-218.

Rácz, J., Pintér, J. N., \& Kassai, S. (2017). Az interpretatív fenomenológiai analízis (IPA) elmélete, módszertana és alkalmazási területei. Budapest: L'Harmattan.

Ritter, I. (2005). Roma fiatalok és a kábitószerek. Budapest: Ifjúsági, Családügyi, Szociális és Esélyegyenlőségi Minisztérium.

Ritter, I., \& Topolánszky, Á. (1999). Jelentés a magyarországi kábítószerhelyzetrôl. Budapest: Ifjúsági és Sportminisztérium.

Rumpf, H. J., Achab, S., Billieux, J., Bowden-Jones, H., Carragher, N., Demetrovics, Zs., et al. (2018). Including gaming disorder in the ICD-11: The need to do so from a clinical and public health perspective: Commentary on: A weak scientific basis for gaming disorder: Let us err on the side of caution (van Rooij et al., 2018). Journal of Behavioral Addictions, 7(3), $556-561$.

Rumpf, H. J., Brandt, D., Demetrovics, Zs., Billieux, J., Carragher, N., Brand, M., et al. (2019). Epidemiological challenges in the study of behavioral addictions: A call for high standard methodologies. Current Addiction Reports, 6(3), 331-337.

Szabó, A. (2016). The Bright and Dark Sides of Exercise Behaviour: Untangling the Paradox. (Doctor of the Hungarian Academy of Sciences) Budapest: ELTE.

Terry, A., Szabó, A., \& Griffiths, M. (2004). The exercise addiction inventory: A new brief screening tool. Addiction Research \& Theory, 12(5), 489-499.

Túry, F. (1995). Gondolatok az evészavarok addikciós elméletéhez. Szenvedélybetegségek, 3, 367-368.

Urbán, R. (2007). A dohányzás egészségpszichológiája. Budapest: Nyitott Könyvmúhely.

Urbán, R. (2010). Smoking outcome expectancies mediate the association between sensation seeking, peer smoking, and smoking among young adolescents. Nicotine \& Tobacco Research, 12(1), 59-68.

Urbán, R. (2016). A serdülókori dohányzás kognitív prediktorainak vizsgálata longitudinális elrendezésben. (Doctor of the Hungarian Academy of Sciences) Budapest: ELTE.

Urbán, R., Kökönyei, G., \& Demetrovics, Zs. (2008). Alcohol outcome expectancies and drinking motives mediate the association between sensation seeking and alcohol use among adolescents. Addictive Behaviors, 33(10), 1344-1352.

Urbán, R., Kun, B., Mózes, T., Soltész, P., Paksi, B., Farkas, J., et al. (2019). A four-factor model of work addiction: the development of the work addiction risk test revised. European Addiction Research, 25(3), 145-160. 
Urbán, R., Magyaródi, T., \& Rigó, A. (2011). Morningness-eveningness, chronotypes and health-impairing behaviors in adolescents. Chronobiology International, 28(3), 238-247.

Vitrai, J. (2009). Tanulmány a „Nemzeti drogstratégia a kábítószerprobléma visszaszoritására” megvalósulásának dokumentum és mélyinterjú-elemzésen alapuló értékeléséról. Budapest: Nemzeti Drogmegelôzési Intézet.

Weinstein, A., Maraz, A., Griffiths, M. D., Lejoyeux, M., \& Demetrovics, Zs. (2016). Compulsive buying - Features and Characteristics of Addiction. In Preedy, V. R. (Ed.), Neuropathology of Drug Addictions and Substance Misuse. Volume 3: General Processes and Mechanisms, Prescription Medications, Caffeine and Areca, Polydrug Misuse, Emerging Addictions and Non-Drug Addictions (pp. 993-1007). London: Academic Press.

\section{ADDICTION PSYCHOLOGY IN HUNGARY: A REVIEW OF THE PAST 30 YEARS DEMETROVICS, ZSOLT - RÁCZ, JÓZSEF}

The current review aims to summarise the history of the past thirty to forty years of the addiction field in Hungary and present a summary of the major developments, research fields, and scientific results. The authors identify three phases in the history of Hungarian addiction science. The initial aspirations of the 1980 s were followed by a significant strengthening and development of the field from the mid-1990s. This, however, mainly happened within Hungary, while in the next decade, from the second half of the 2000s, the international presence of the Hungarian addiction research field became more significant. Following the historical summary, the authors present the major research teams and research directions and describe the main policy developments.

Keywords: addiction science, psychology, history, research directions

A cikk a Creative Commons Attribution 4.0 International License (https://creativecommons. org/licenses/by/4.0/) feltételei szerint publikált Open Access közlemény, melynek szellemében a cikk bármilyen médiumban szabadon felhasználható, megosztható és újraközölhetô, feltéve, hogy az eredeti szerzô és a közlés helye, illetve a CC License linkje és az esetlegesen végrehajtott módosítások feltüntetésre kerülnek. (SID_1) 